удК 347.9

DOI https://doi.org/10.32837/apdp.v0i90.3201

М. П. Баб’юк, О. А. Руденко

\title{
ПІДСТАВИ ТА ПОРЯДОК ПЕРЕДАЧІ СПРАВИ З ОДНОГО СУДУ ДО ІНШОГО В ЦИВІЛЬНОМУ СУДОЧИНСТВІ
}

Постановка проблеми. Для забезпечення права кожного на справедливий суд та повагу до інших гарантованих Конституцією і законами України прав і свобод у системі судоустрою утворюються і функціонують суди різних ланок та інстанцій, компетенція і повноваження яких щодо розгляду та вирішення тих чи інших спорів визначаються процесуальним законом. Так, у ч.ч. 1, 8 ст. 19 ЦПК України встановлено категорії справ, що слухаються за правилами цивільного судочинства [1]. Інстанційна юрисдикція визначає обсяг повноважень судів різних інстанцій щодо розгляду і вирішення цивільних справ (ст.ст. 23-25 ЦПК України). Водночас розмежування компетенції щодо здійснення правосуддя у цивільних справах між судами однієї ланки залежно від території, на яку поширюються їх повноваження, здійснюється за правилами територіальної юрисдикції (підсудності) (ст.ст. 26-30 ЦПК України). Разом із тим, на практиці непоодинокими є випадки пред'явлення позову з порушенням правил територіальної підсудності, встановлених у ЦПК України, або неможливості здійснення розгляду і вирішення справи компетентним судом з об'єктивних причин. За таких обставин для забезпечення виконання завдань цивільного судочинства передбачено процесуальний порядок передачі справи з одного суду до іншого.

Аналіз останніх досліджень і публікацій. Деякі аспекти передачі справи з одного суду до іншого висвітлювали у своїх працях такі вчені як А.Г. Гулик [2], А.Х. Джавадов [3], А.П. Задорожна [4], О. Єфімов [5], Н.Є. Керноз та І.В. Берднік [6], Ю.І. Полюк [7], Т.А. Стоянова й І.М. Іліопол [8] та ін. Зазначеними науковцями процесуальні особливості передачі справи досліджувалися при з'ясуванні змісту правил підсудності у цивільному судочинстві та наслідків їх порушення, при здійсненні аналізу змін у правовому регулюванні цивільної юрисдикції у зв’язку з прийняттям Закону України «Про внесення змін до Господарського процесуального кодексу України, Цивільного процесуального кодексу України, Кодексу адміністративного судочинства України та інших законодавчих актів» від 03.10.2017 p. № 2147-VIII [9] та у контексті вивчення умов реалізації права на звернення до суду за захистом. Підставам і порядку передачі цивільної справи з одного суду до іншого не було присвячено окремого наукового дослідження, що свідчить про актуальність наукових розвідок у цій сфері.

Метою статті є визначення підстав і процесуального порядку передачі справи з одного суду до іншого, та вироблення рекомендацій щодо удосконалення правового регулювання у досліджуваній сфері.

Виклад основного матеріалу. Вичерпний перелік підстав для передачі справи з одного суду до іншого у цивільному судочинстві передбачено у ч. 1 ст. 31 ЦПК 
України, відповідно до якої суд передає справу на розгляд іншому суду, якщо: 1) справа належить до територіальної юрисдикції (підсудності) іншого суду; 2) після задоволення відводів (самовідводів) чи з інших підстав неможливо утворити новий склад суду для розгляду справи; 3) ліквідовано або з визначених законом підстав припинено роботу суду, який розглядав справу.

Треба сказати, що деякі науковці передачу справи з одного суду до іншого називають зміною підсудності справи. Так, О. Єфімов зміну підсудності визначає як процесуальні дії з передачі справи, прийнятої без порушення правил про підсудність, для провадження в іншому суді [5, с. 38]. Схожої думки дотримується визначення пропонує Г.Л. Осокина, за переконанням якої зміною підсудності є передача цивільної справи на розгляд з одного суду до іншого всупереч встановленим правилам про підсудність [10, с. 32-33].

Видається, такі підходи не узгоджуються з нині чинними положеннями ст. 31 ЦПК України, відповідно до якої однією з підстав для направлення справи з одного суду до іншого є пред'явлення позову з порушенням правил територіальної юрисдикції (підсудності). Вказане означає, що передачі підлягає також і та цивільна справа, провадження у якій відкрито з порушенням правил підсудності, при цьому направляється вона до суду, якому підсудна.

Окрім того, згідно з підходом законодавця зміна територіальної підсудності судових справ може здійснюватися лише законами України. Так, відповідно до ч. 3 ст. 26 Закону України «Про правовий режим воєнного стану» від 12.05.2015 р. № 389-VIII у разі неможливості здійснювати правосуддя судами, які діють на території, на якій введено воєнний стан, законами України може бути змінена територіальна підсудність судових справ, що розглядаються в цих судах, або в установленому законом порядку змінено місцезнаходження судів [11]. Окрім цього, у ст. 12 Закону України «Про забезпечення прав і свобод громадян та правовий режим на тимчасово окупованій території України» від 15.04.2014 р. № 1207-VII зазначено про зміну територіальної підсудності цивільних справ, підсудних розташованим на території Автономної Республіки Крим та міста Севастополя судам, та вказано на необхідність забезпечення їх розгляду місцевими загальними судами міста Києва, що визначаються Апеляційним судом міста Києва [12]. У ст. 1 Закону України «Про здійснення правосуддя та кримінального провадження у зв'язку з проведенням антитерористичної операції» від 12.08.2014 р. № 1632-VII зазначено, що у зв’язку з неможливістю здійснювати правосуддя окремими судами в районі проведення антитерористичної операції змінити територіальну підсудність судових справ, підсудних розташованим в районі проведення антитерористичної операції таким судам, та забезпечити розгляд цивільних справ, підсудних місцевим загальним судам, розташованим в районі проведення антитерористичної операції місцевими загальними судами, що визначаються головою Верховного Суду [13].

Як видно, територіальну підсудність справи може бути змінено лише шляхом прийняття закону України, з дня набрання чинності яким позовні заяви, заяви про видачу судового наказу, заяви у справах окремого провадження подаються до місцевих загальних судів за зміненими правилами. Передача справи здійснюється 
з суду, до якого особа вже звернулася, до іншого суду, з підстав, передбачених ч. 1 ст. 31 ЦПК України, для розгляду і вирішення.

Отже, неправильно вважати передачу справи з одного суду до іншого зміною підсудності. Разом із тим, вказані правові категорії тісно пов'язані між собою, оскільки у разі зміни підсудності справи, що перебувають в одному суді, направляються для продовження розгляду до іншого органу судової влади. Наприклад, згідно з ст. 12 Закону України «Про забезпечення прав і свобод громадян та правовий режим на тимчасово окупованій території України» від 15.04.2014 р. № 1207VII справи, що перебувають у провадженні судів, розташованих на території Автономної Республіки Крим та міста Севастополя, та розгляд яких не закінчено, передаються судам відповідно до встановленої цим Законом підсудності, протягом десяти робочих днів з дня набрання ним чинності або з дня встановлення такої підсудності. Таке ж положення передбачено ч. 3 ст. 1 Закону України «Про здійснення правосуддя та кримінального провадження у зв'язку з проведенням антитерористичної операції» від 12.08.2014 р. № 1632-VII. Як видно, зміна територіальної підсудності справи також є підставою для передачі справи з одного суду до іншого, але у ч. 1 ст. 31 ЦПК України вона відсутня. Видається, доцільно передбачити зміну підсудності справи як окрему підставу для передачі справи з одного суду до іншого, оскільки нині на законодавчому рівні передбачено таку можливість шляхом прийняття відповідного закону.

Передача справи на розгляд іншого суду, до територіальної юрисдикції (підсудності) якого вона належить, здійснюється на підставі ухвали не пізніше п’яти днів після закінчення строку на їі оскарження, а у випадку подання апеляційної скарги - не пізніше п'яти днів після залишення її без задоволення (ч. 3 ст. 31 ЦПК України). При цьому така передача може бути здійснена як до відкриття провадження у справі, так і на стадіях підготовчого провадження та розгляду справи по суті.

До набрання чинності Законом України «Про внесення змін до Господарського процесуального кодексу України, Цивільного процесуального кодексу України, Кодексу адміністративного судочинства України та інших законодавчих актів» від 03.10.2017 р. № 2147-VIII встановлення порушення правил підсудності під час розв' язання питання про відкриття провадження у справі було підставою для повернення позовної заяви позивачеві (п. 4 ч. 3 ст. 121 ЦПК України 2004 р.), а не для передачі справи до іншого суду, якому вона підсудна. Слід погодитися з думкою А.П. Задорожної, яка зауважила, що «внесені зміни щодо процесуальних наслідків порушення правил підсудності тепер роблять право на судовий захист більш доступним та оперативним, оскільки прибрані формальні перепони на звернення до суду та не витрачається час на листування з різноманітними судами» [4, с. 146].

Окрім того, згідно з положеннями п. 2 ч. 1 ст. 116 ЦПК України 2004 р. допускалася передача справи з одного суду до іншого після відкриття провадження у зв'язку з порушенням правил підсудності порушення допускалося, однак лише до початку судового розгляду. За нині чинним ЦПК України така умова відсутня. 3 цього приводу у літературі зауважено, що «це $є$ неправильним і цю умову для такої передачі цивільної справи варто повернути, інакше розгляд цивільної справи може 
затягнутися надовго» [4, с. 148]. Із такою позицією повністю погодитися не можна, оскільки нині порушення правил територіальної юрисдикції (підсудності) є підставою для скасування судового рішення, яким закінчено розгляд справи, в апеляційному і касаційному порядках, крім випадків коли учасник справи при розгляді справи в суді першої інстанції без поважних причин не заявляв про непідсудність справи (ст. 378, п. 6 ч. 1, ч. 2 ст. 411 ЦПК України). 3 огляду на це, видається, правильним $є$ надання суду першої інстанції протягом усього строку розгляду справи можливості виправити помилку, допущену при вирішенні питання про відкриття провадження у справі, що полягала у порушенні правил територіальної підсудності.

У ч. 2 ст. 31 ЦПК України передбачено положення про те, що справа, прийнята судом до свого провадження з додержанням правил підсудності, повинна бути ним розглянута і в тому випадку, коли в процесі розгляду вона стала підсудною іншому суду, за винятком випадків, коли внаслідок змін у складі відповідачів справа належить до виключної підсудності іншого суду. Із таким законодавчим положенням не погодилася А.П. Задорожна, яка вказала, що у цій ситуації порушуватиметься право заміненого відповідача на суд, встановлений законом. 3 огляду на це, науковцем запропоновано заборонити здійснювати заміну неналежного відповідача у разі, якщо це потягне за собою непідсудність справи суду, що здійснює їі розгляд, за умови неможливості передачі справи до іншого суду, за винятком випадку, коли відповідач погодиться на слухання справи у цьому суді [4, с. 168].

Думається, задоволення чи відмова у задоволенні клопотання позивача про заміну неналежного відповідача не може обгрунтовуватися необхідністю збереження підсудності справи суду, яким вона розглядається, чи залежати від можливості передачі справи на розгляд до іншого суду. Разом із тим, заслуговує на увагу твердження про порушення права належного відповідача на розгляд справи у суді, визначеному за правилами загальної територіальної підсудності. 3 огляду на це у випадку, якщо в процесі розгляду цивільна справа стане непідсудною суду, яким вона розглядається, то її треба передавати на розгляд іншого суду, але за клопотанням відповідача.

Наступною підставою для передачі справи з одного суду до іншого є неможливість утворення нового складу суду для розгляду справи після задоволення відводів (самовідводів) чи за наявності обставин, за яких недопустимою є повторна участь судді у розгляді справи. 3 цієї підстави направлення справи здійснюється на розгляд суду, найбільш територіально наближеного до суду, яким розглядається справа, на підставі розпорядження голови суду, що є не судовим рішенням, а тому не може оскаржуватись в апеляційному порядку (п. 2 ч. 1 ст. 31, ч. 4 ст. 31, ч. 3 ст. 41 , ч. 1 ст. 258 ЦПК України).

У літературі під «найбільш територіально наближеним судом» розуміється суд у сусідній адміністративно-територіальній одиниці, що визначається на розсуд суду, який приймає рішення про передачу справи [14, с. 289]. Видається, такий підхід не дозволить правильно визначити орган судової влади, якому має бути адресована справа на підставі п. 2 ч. 1 ст. 31 ЦПК України, оскільки сусідніх адміністративно-територіальних одиниць та відповідно і судів може бути декілька. Переконливішою, як уявляється, є позиція А.П. Задорожної, яка найбільшу тери- 
торіальну наближеність визначає як найкоротшу відстань шляхами сполучення між двома судами в різних адміністративно-територіальних одиницях - судом, що передає цивільну справу, та судом, якому передають цивільну справу [4, с. 160]. При цьому науковцем справедливо зауважено, що найбільш територіально наближений суд має знаходитися в межах території, на яку поширюються повноваження суду апеляційної інстанції для судових рішень, прийнятих судом, від якого передається цивільна справа [4, с. 161].

Слід сказати, що у науковій літературі запропоновано при виборі найбільш територіально наближеного суду враховувати не тільки територіальну ознаку (найкоротша відстань), а й штатну, що передбачає наявність достатньої кількості суддів у суді, до якого передається справа, з метою уникнення їх перенавантаження [4, с. 160]. Із такою пропозицією неможливо погодитися, оскільки при визначенні кількісного складу суду обов'язково враховується судове навантаження (ч. 6 ст. 19 Закону України «Про судоустрій і статус суддів» від 02.06.2016 р. № 1402-VIII [15]), а тому немає підстав вважати, що у суді, до якого передається справа, недостатня кількість суддів.

А.П. Задорожна не погодилася із висловленими у науковій літературі пропозиціями надати суду вищої інстанції повноваження визначати суд, до якого слід передати цивільну справу у випадку, передбаченому п. 2 ч. 1 ст. 31 ЦПК України, на підставі заяви відведеного судді, оскільки фактично у цій ситуації йдеться про заміну передачі цивільної справи з одного суду іншому на підсудність, яка визначається ухвалою вищого суду. Із таким обгрунтуванням погодитися не можна, оскільки пропонується лише надати суду вищої інстанції повноваження визначити суд, до якого слід передати справу, тобто про первинне визначення підсудності справи за ухвалою суду не йдеться. Разом із тим, видається, недоцільно ускладнювати порядок визначення суду, до якого необхідно направити справу для розгляду і вирішення, так як суд вищої інстанції ймовірніше визначатиме той суд, що є найбільш територіально наближеним до суду, з якого передається справа.

Ще однією підставою для передачі справи з одного суду до іншого є ліквідація або припинення роботи суду, який розглядав справу.

Слід сказати, що суд ліквідовується законом, проект якого вносить до Верховної Ради України Президент України після консультацій з Вищою радою правосуддя. Підставами для ліквідації суду є такі: зміна визначеної законом системи судоустрою, необхідність забезпечення доступності правосуддя, оптимізації видатків державного бюджету або зміна адміністративно-територіального устрою (ч.ч. 1-2, 4 ст. 19 Закону України «Про судоустрій і статус суддів» від 02.06.2016 р. № 1402-VIII). Роботу суду може бути припинено у зв’язку зі стихійним лихом, військовими діями, заходами щодо боротьби з тероризмом або іншими надзвичайними обставинами за рішенням Вищої ради правосуддя, що ухвалюється за поданням Голови Верховного Суду (ч. 7 ст. 147 Закону України «Про судоустрій і статус суддів» від 02.06.2016 р. № 1402-VIII).

У ч. 5 ст. 31 ЦПК України зазначено, що у разі ліквідації або припинення роботи суду справи, що перебували у його провадженні, невідкладно передаються до суду, визначеного відповідним законом або рішенням про припинення роботи 
суду, а якщо такий суд не визначено - до суду, що найбільш територіально наближений до суду, який ліквідовано або роботу якого припинено. Вказане положення конкретизовано в абз. 2 ч. 6 ст. 146 Закону України «Про судоустрій і статус суддів від 02.06.2016 р. № 1402-VIII, відповідно до якого судові справи та матеріали проваджень, що перебувають у володінні суду, що ліквідується, передаються негайно, до дня початку роботи новоутвореного суду.

Окремо варто зупинитися на тому, що ч. 5 ст. 19 Закону України «Про судоустрій і статус суддів» від 02.06.2016 р. № 1402-VIII передбачено утворення нового суду шляхом реорганізації (злиття, поділу) судів. У науковій літературі зауважено, що ці законодавчі приписи суперечать загальним положенням про юридичну особу, оскільки шляхом реорганізації, як і ліквідації, юридична особа припиняється, а не утворюється [16, с. 76]. Додатковим аргументом на підтвердження вказаних доводів є те, що відповідно до п. 1 ч. 2 ст. 53, ч. 3 ст. 82, ст. 117 Закону України «Про судоустрій і статус суддів» від 02.06.2016 р. № 1402-VIII реорганізація суду є підставою для переведення судді до іншого суду без його згоди і без конкурсу або звільнення з посади у зв'язку з незгодою на переведення до іншого суду. Зі змісту викладеного випливає, що у разі реорганізації суду усі судові справи, що перебувають у його провадженні, мають бути передані до іншого суду, визначеного відповідним законом, а у випадку, якщо такий суд не визначено, - до суду, що найбільш територіально наближений до суду, який реорганізовується.

Висновки. Отже, за нині чинним ЦПК України передача справи з одного суду до іншого у цивільному судочинстві - це направлення справи з суду, до якого особа звернулася за захистом, до іншого органу судової влади для розгляду і вирішення у випадках належності такої справи до територіальної юрисдикції (підсудності) іншого суду, неможливості утворення нового складу суду для розгляду справи після задоволення відводів (самовідводів) або з інших підстав, а також ліквідації або припинення роботи суду, який розглядав справу.

Для забезпечення виконання завдань цивільного судочинства до підстав для передачі справи з одного суду до іншого слід віднести реорганізацію суду, а також зміну підсудності справи законом. Окрім цього, у ЦПК України слід передбачити ще один виняток із правила про те, справа, прийнята судом до свого провадження з додержанням правил підсудності, повинна бути розглянута і в тому випадку, якщо в процесі розгляду справи вона стала підсудною іншому суду, - крім випадку, коли внаслідок змін у складі відповідачів, зміни предмета і підстав позову справа належить до підсудності суду за місцем проживання або місцезнаходженням відповідача за умови подання ним клопотання про передачу справи на розгляд до такого суду.

Думається, внесення вказаних змін до ЦПК України сприятиме забезпеченню виконання завдань цивільного судочинства. 


\section{Jimepamypa}

1. Цивільний процесуальний кодекс України: Закон України від 18.03.2004 № 1618-IV. URL: https://zakon.rada.gov.ua/laws/show/1618-15 (дата звернення: 27.05.2021).

2. Гулик А.Г. Проблеми формування оптимальних правил підсудності цивільних справ. Публічне і приватне право. 2019. № 4. C. 51-55. URL: http://pp-law.in.ua/archive/4_2019/12.pdf.

3. Джавадов Хикмет Аловсат оглы. Подсудность гражданських дел: понятие, виды, перспективное регулирование. Право.иа. 2017. № 2. С. 137-144. URL: http://nbuv.gov.ua/UJRN/pravo_2017_2_24.

4. Задорожна А.П. Підсудність у цивільному процесі України: дис... канд. юрид. наук: 12.00.03 // Науково-дослідний інститут приватного права і підприємництва імені академіка Ф.Г. Бурчака НАПрН України. Київ, 2018. 250 с.

5. Єфімов О. Правові засади підсудності цивільних справ. Юридична Україна. 2015. № 6. С. 29-39. URL: http://nbuv.gov.ua/UJRN/urykr_2015_6_7

6. Керноз Н.Є., Берднік І.В. Проблемність законодавчого врегулювання підсудності та її видів у національному судочинстві. Молодий вчений. 2014. № 11(14). C. 160-165. URL: http://nbuv.gov.ua/ UJRN/molv_2014_11\% $2814 \% 29 \_42$.

7. Полюк Ю.І. Вплив територіальної юрисдикції (підсудності) при реалізації права на звернення до суду за захистом у цивільному судочинстві України. Часопис иивілістики. 2019. № 34. С. 58-63. URL: http://chascyvil.onua.edu.ua/index.php/chc/article/download/173/61.

8. Стоянова Т.А., Іліопол І.М. Науково-практичний аналіз цивільної юрисдикції першої та апеляційної інстанцій у світлі прийняття нового Цивільного процесуального кодексу. Науковий вісник Ужгородського національного університету. Серія Право. 2017. Вип. 47. Т. 1. С. 13-16. URL: http://www.visnyk-juris.uzhnu.uz.ua/file/No.47/part_2/4.pdf.

9. Про внесення змін до Господарського процесуального кодексу України, Цивільного процесуального кодексу України, Кодексу адміністративного судочинства України та інших законодавчих актів: Закон України від 03.10.2017 № 2147-VIII. Відомості Верховної Ради України. 2017. № 48. Ст. 436.

10. Осокина Г. Л. Подведомственность и подсудность дел гражданского судопроизводства: учеб. пособ. Томск: Изд-во Томск. ун-та, 1993. 40 с.

11. Про правовий режим воєнного стану: Закон України від 12.05.2015 № 389-VIII. URL: https://zakon.rada.gov.ua/laws/show/389-19\#Text (дата звернення: 27.05.2021)

12. Про забезпечення прав і свобод громадян та правовий режим на тимчасово окупованій території України: Закон України від 15.04.2014 № 1207-VII. URL: https://zakon.rada.gov.ua/laws/ show/1207-18\#Text (дата звернення: 27.05.2021)

13. Про здійснення правосуддя та кримінального провадження у зв'язку з проведенням антитерористичної операції: Закон України від 12.08.2014 № 1632-VII. URL: https://zakon.rada.gov.ua/laws/ show/1632-18\#Text (дата звернення: 27.05.2021)

14. Курс цивільного процесу: підручник / В.В. Комаров, В.А. Бігун, В.В. Баранкова та ін.; за ред. В. В. Комарова. Х.: Право, 2011. 1352 с.

15. Про судоустрій і статус суддів: Закон України від 02.06.2016 № 1402-VIII. Відомості Верховної Ради України. 2016. № 31. Ст. 545

16. Калашник О.А. Правовий статус місцевих загальних судів в Україні : дис. ... канд. юрид. наук : 12.00.10. Одеса, 2016. 234 c. URL: http://dspace.onua.edu.ua/bitstream/handle/11300/4240/ Diss_Kalashnik.PDF?sequence $=4 \&$ isAllowed $=\mathrm{y}$. 


\section{Анотація}

Баб’юк М. П., Руденко О. А. Підстави та порядок передачі справи з одного суду до іншого в цивільному судочинстві. - Стаття.

Статтю присвячено визначенню підстав і процесуального порядку передачі справи з одного суду до іншого у цивільному судочинстві. Під передачею справи з одного суду до іншого запропоновано розуміти направлення справи з суду, до якого особа звернулася за захистом, до іншого органу судової влади для розгляду і вирішення у випадках належності такої справи до територіальної юрисдикції (підсудності) іншого суду, неможливості утворення нового складу суду для розгляду справи після задоволення відводів (самовідводів) або з інших підстав, а також ліквідації або припинення роботи суду, який розглядав справу.

Обгрунтовано, що передачу цивільної справи з одного суду до іншого неправильно ототожнювати зі зміною підсудності справи. Зазначено, що правильним є надання суду першої інстанції протягом усього строку розгляду справи можливості передати справу, провадження у якій було відкрито 3 порушенням правил підсудності, до суду, якому вона підсудна. Зроблено висновок про те, що за нині чинним цивільним процесуальним законодавством України цивільну справу, що стала непідсудною суду в процесі розгляду справи, може бути передано лише у випадку належності такої справи до виключної підсудності іншого суду внаслідок змін у складі відповідачів (залучення співвідповідача, заміна неналежного відповідача). Аргументовано, що при передачі цивільної справи у випадках, визначених у ч. 1 ст. 31 ЦПК України, до найбільш територіально наближеного суду має враховуватися лише територіальна ознака.

3 метою забезпечення виконання завдань цивільного судочинства запропоновано до підстав для передачі справи з одного суду до іншого віднести реорганізацію суду, а також зміну законом підсудності справи. Одним із шляхів забезпечення права відповідача на суд, встановлений законом, визначено закріплення на законодавчому рівні необхідності передачі справи до суду за зареєстрованим у встановленому законом порядку місцем його проживання чи місцезнаходженням у випадку, коли внаслідок змін у складі відповідачів, зміни предмета і підстав позову справа стала непідсудною суду, яким розглядається, за умови подання до суду відповідного клопотання.

Ключові слова: підсудність, передача справи, цивільне судочинство, територіальна юрисдикція, суд, зміна підсудності.

\section{Summary}

Babiuk M.P., Rudenko O. A. Grounds and procedure for transferring a case from one court to another in civil proceedings. - Article.

The article is devoted to determining the grounds and procedural procedure for transferring a case from one court to another in civil proceedings. Under the transfer of a case from one court to another it is proposed to understand the referral of the case from the court to which the person applied for protection, to another judicial authority for consideration and resolution in cases of such case to the territorial jurisdiction of another court, the impossibility of forming a new court for consideration of the case after satisfaction of recusals (self-recusals) or on other grounds, as well as liquidation or termination of the court that considered the case.

It is substantiated that the transfer of a civil case from one court to another should be incorrectly equated with a change in the jurisdiction of the case. It is stated that it is correct to provide the court of first instance with the opportunity to transfer the case in which the proceedings were opened in violation of the rules of jurisdiction to the court to which it is subject. It is concluded that under the current civil procedural legislation of Ukraine, a civil case that became out of court in the process of consideration of the case can be transferred only if such a case belongs to the exclusive jurisdiction of another court due to changes in defendants (involvement of co-defendant, replacement of improper defendant). It is argued that the transfer of a civil case in the cases specified in Part 1 of Art. 31 Civil Procedure Code of Ukraine, to the most territorially close court should be taken into account only the territorial feature.

In order to ensure the implementation of the tasks of civil proceedings, it is proposed to include the reorganization of the court, as well as the change in the jurisdiction of the case by law as grounds for transferring the case from one court to another. One of the ways to ensure the right of the defendant to a court established by law is to enshrine in law the need to transfer the case to court at the legally registered place of residence or location in the event that due to changes in the composition of the defendants out of the jurisdiction of the court under consideration, provided that a corresponding petition is submitted to the court.

Key words: jurisdiction, transfer of case, civil proceedings, territorial jurisdiction, court, change of jurisdiction. 